\title{
“Annona crassiflora MART. FRUIT PULP EFFECTS ON BIOCHEMICAL PARAMETERS AND RAT COLON CARCINOGENESIS"
}

\author{
Efeitos da polpa do fruto de Annona crassiflora Mart., \\ nos parâmetros bioquímicos e na carcinogênese de colon de ratos
}

\author{
Vinícius Paula Venâncioํㅜ Eric Batista Ferreira ${ }^{2}$, Maísa Ribeiro Pereira Lima Brigagão², \\ Fernanda Borges de Araújo Paula ${ }^{3}$, Luis Fernando Barbisan ${ }^{4}$ Luciana Azevedo $^{5}$
}

\begin{abstract}
A. crassiflora Mart. a Brazilian savannah fruit, is a source of phytochemical compounds that possess a wide array of biological activities, including free radical scavenging. This native fruit proved to potentialize the mutagenic process in previous in vivo investigations. The aim of the present study was to investigate the effects of A. crassiflora Mart. pulp intake on colonic cell proliferation and on the development of Aberrant Crypt Foci (ACF) in male Wistar rats. The animals were fed with either a commercial diet or a diet supplemented with A. crassiflora Mart. pulp mixed in 1\%, 10\% or 20\% (w/w) for 4 weeks or 20 weeks. The carcinogen 1,2-dimethylhydrazine dihydrochloride (4 doses, $40 \mathrm{mg} \mathrm{kg}^{-1}$ each) was used to induce colonic ACF. After euthanasia, the blood, liver and colon samples were collected for biochemical determinations, oxidative stress or ACF development analysis, respectively. Immunohistochemical analyses of the colonic mucosa were performed using antibodies against proliferating cell nuclear antigen (PCNA) in normal-appearing colonic crypt and $\beta$-catenin in ACF. There was no ACF development in the colon from groups treated with A. crassiflora Mart. pulp. Also, the biochemical and oxidative stress analysis, PCNA labeling and ACF development (number, multiplicity or cellular localization of $\beta$-catenin) were unchanged as a result of marolo pulp intake. Thus, the present results suggest that $A$. crassiflora Mart. pulp intake did not exert any protective effect in the colon carcinogenesis induced by DMH in rats.
\end{abstract}

Index terms: Aberrant crypt foci, brazilian savannah, dimethylhydrazine, immunohistochemistry, oxidative stress.

\section{RESUMO}

O marolo (Annona crassiflora Mart.) é uma fruta do cerrado brasileiro e fonte de compostos fitoquímicos com grande variedade de atividades biológicas, incluindo eliminação de radicais livres. Entretanto, em estudos anteriores, essa fruta nativa mostrou-se como potencializadora do processo mutagênico in vivo. Objetivou-se, neste estudo, investigar os efeitos da ingestão da polpa de marolo sobre a proliferação de células do cólon e no desenvolvimento de lesões pré-neoplásicas por meio de focos de criptas aberrantes (ACF) em ratos Wistar. Os animais foram alimentados com dieta comercial ou suplementada com polpa de marolo nas proporções de $1 \%, 10 \%$ ou $20 \%$ (m/ $\mathrm{m}$ ), durante 4 semanas, ou 20 semanas. Como agente indutor da carcinogênese de cólon foi utilizado o dicloridrato de 1,2-dimetilhidrazina (4 doses, $40 \mathrm{mg} \mathrm{kg}^{-1}$ cada). Após a eutanásia, as amostras de sangue, fígado e cólon foram coletadas para determinações bioquímicas, estresse oxidativo ou análise de desenvolvimento de Focos de Criptas Aberrantes (FCA), respectivamente. A análise imunohistoquímica da mucosa do cólon foi realizada, utilizando anticorpos contra o antígeno nuclear de proliferação celular (PCNA) e $\beta$-catenina em FCA. Não houve desenvolvimento de FCA no cólon nos grupos tratados exclusivamente com polpa de marolo. Além disso, a análise de estresse oxidativo e bioquímico, PCNA e de desenvolvimento (multiplicidade, número ou localização celular da $\beta$-catenina) permaneceram inalteradas como resultado da ingestão da polpa de marolo. Assim, os resultados sugerem que a ingestão do fruto não exerceu efeito protetor contra a carcinogênese induzida pela DMH e, principalmente, não apresentou efeitos mutagênicos ou carcinogênicos pelos métodos avaliados.

Termos para indexação: Focos de cripta aberrantes, cerrado brasileiro, dimetilhidrazina, imunohistoquímica, estresse oxidativo.

(Received in march 4, 2013 and approved in june 28, 2013)

\section{INTRODUCTION}

Annonaceae is a family of plants found in the central Brazilian savannah that contains a great variety of native fruits, including the Annona crassiflora Mart.. The pulp of the A. crassiflora Mart. contains carotenoids, polyphenols, acetogenins (tetrahydrofuranic acetogenins or annonaceous acetogenins), tocopherols, flavonoids and some vitamins and minerals (DRAGANOet al., 2010; ROESLER et al., 2007). Given their selective effects, some of these compounds are potential anti-cancer agents against different human cancer cell lines in vitro (JASWIR et al., 2012).

\footnotetext{
'Universidade Federal de Alfenas/UNIFAL - Faculdade de Ciências Farmacêuticas - 700 - Gabriel Monteiro da Silva - Alfenas - MG - Brasil venancio.vinicius@gmail.com

2Universidade Federal de Alfenas/UNIFAL - Instituto de Ciências Exatas - Alfenas - MG - Brasi

3Universidade Federal de Alfenas/UNIFAL - Faculdade de Ciências Farmacêuticas - Alfenas - MG - Brasil

${ }^{4}$ Universidade Estadual Paulista "Júlio de Mesquita Filho"/UNESP - Instituto de Biociências de Botucatu - Botucatu - SP - Brasil

${ }^{5}$ Universidade Federal de Alfenas/UNIFAL - Faculdade de Nutrição - Alfenas - MG - Brasil
} 
In vitro and in vivo studies indicate that either pulp or ethanolic extracts of $A$. crassiflora Mart.o leaves did not present potential mutagenic or genotoxic effects, as evaluated using micronuclei, SOS-Inductest or Ames tests (DRAGANO et al., 2010; VILAR; FERRI; CHENCHEN, 2011). Although A. crassiflora Mart. pulp, peel and seeds demonstrated antioxidant activity in vitro (ROESLER et al., 2007), Vilar et al. (2008) showed both antimutagenic and cytotoxic effects of an ethanolic extract of marolo leaves on bone marrow cells. Also, Dragano et al. (2010) showed that diets supplemented with $10 \%$ and $20 \%$ (w/w) A. crassiflora Mart. pulp acted as a cyclophosphamide booster in the same mouse bone marrow micronucleus test. Once this fruit pulp effects remain understudied in literature, specially regarding carcinogenicity and anticarcinogenicity, the present work was performed to investigate, in vivo, the A. crassiflora Mart. pulp properties. This pulp was analyzed as it is consumed in the realistic food matrix, where its different bioactive compounds may interact with each other resulting in a wide range of action possibilities. For this purpose, this fruit was biologically evaluated for its potential protective effects on a colon cancer model, evaluating cellular proliferation in the colonic mucosa and liver oxidative stress in male Wistar rats.

\section{MATERIAL AND METHODS}

The fruits of A. crassiflora Mart. were harvested from the savannah ecoregion in Machado, MG, Brazil ( $\left.21^{\circ} 40^{\prime} 29^{\prime \prime} \mathrm{S} ; 45^{\circ} 55^{\prime} 11^{\prime \prime} \mathrm{W}\right)$ and a sample of this specimen is stored in the Alfenas Federal University Herbarium (UALF, ID: 2278). Experimental diets were formulated into pellets containing a mixture of commercial diet (Nuvilab CR-1, Nuvital, Paraná, Brazil) and $1 \%, 10 \%$ or $20 \%(\mathrm{w} / \mathrm{w})$ in natura A. crassiflora pulp (AZEVEDO et al., 2003). The compositional analysis of all diets (moisture, fat, protein, ash and carbohydrate) was performed in triplicate. Moisture was determined by loss while drying with an infrared moisture analyzer (IV2000, Gehaka, São Paulo, SP, Brazil) for $8 \mathrm{~min}$ at 120 ${ }^{\circ} \mathrm{C}$ (LUTZ, 2008). The total nitrogen content was analyzed by the Kjeldahl procedure ( 6.25 conversion factor to protein) and the ash content was determined by the incineration of samples at $550^{\circ} \mathrm{C}$ in a muffle furnace. Fat content was measured in a Soxhlet system by solvent extraction (ASSOCIATION OF OFFICIAL ANALYTICAL CHEMISTS-AOAC, 2000) and carbohydrates were calculated to the remainder (the difference using the fresh weight-derived). Details regarding the chemistry profile of the pulp used in this study have previously been described in Dragano et al. (2010).

The animals used in this study were handled in accordance with the Ethical Principles for Animal Research and the experimental design was approved by Alfenas Federal University Animal Ethics Committee (process 344/2011). Four-week old male Wistar rats (Rattus norvegicus) were obtained from CEMIB (UNICAMP, Campinas SP, Brazil). The animals were randomly allocated into two experimental protocols: four weeks (A) and 20 weeks (B) treatment. In both experiments, the animals were randomly assigned to one of eight groups (10 rats/group). Groups 1-4 received four subcutaneous (s.c.) injections of 1,2dimethylhydrazine dihydrochloride (DMH, Sigma, St. Louis, MO, USA) at $40 \mathrm{mg} \mathrm{kg}^{-1}$ body weight (b.wt.) on $8^{\text {th }}, 11^{\text {th }}, 15^{\text {th }}$ and $18^{\text {th }}$ days. Groups 5-8 received similar s.c. injections of EDTA (ethylenediaminetetracetic acid) solution pH 6.5 (DMH vehicle) (DIAS et al., 2010). The animals were fed either with the commercial diet (groups 1 and 5) or with A. crassiflora Mart. pulp mixed in the commercial diet at $1 \% \mathrm{w} / \mathrm{w}$ (groups 2 and 6), $10 \% \mathrm{w} / \mathrm{w}$ (groups 3 and 7) or 20\% w/w (groups 4 and 8) during 4 weeks or 20 weeks. Food consumption and body mass were measured once a week throughout the experimental period. At the end of the two experiments, all animals were anesthetized with ketamine hydrochloride (100.0 $\mathrm{mg} \mathrm{kg}^{-1}$ b.wt.) and xylazine hydrochloride $\left(10.0 \mathrm{mg} \mathrm{kg}^{-1}\right.$ b.wt.) and were sacrificed by exsanguination. At necropsy, the blood, liver and colon of each animal were removed. All animals were fasted for 12 hours before the blood sampling.

Nutritional parameters, such as growth performance, body mass gain and food consumption, were evaluated as follows: body mass gain $(\mathrm{g} / \mathrm{day})=($ final body mass - initial body mass)/number of interval days; Food intake $(\mathrm{g} /$ day $)=($ final diet mass - initial diet mass $) /$ number of interval days (KUMAR et al., 2012).

\section{Tissue processing and $\mathrm{ACF}$ analysis}

After euthanasia, the entire colon was removed, longitudinally opened, rinsed with $0.9 \%$ (w/v) $\mathrm{NaCl}$ solution and fixed flat in buffered formalin at $4 \%$ for $24 \mathrm{~h}$. For Aberrrant Crypt Foci (ACF) count, the tissue was stained with methylene blue for $1 \mathrm{~min}$ (LI et al., 2011). Analysis and quantification of ACF were performed according to Bird's (BIRD, 1995) criteria. The number of ACF in one hundred sequential microscopic fields and the number of aberrant crypts in each ACF were determined using light microscopy (40× magnification). After being decolorized using 70\% (v/ 
v) ethanol, the colons were re-stained with a solution of $1 \%(\mathrm{w} / \mathrm{v})$ toluidine blue (TB) in $3 \%(\mathrm{v} / \mathrm{v})$ acetic acid (TB, $\mathrm{pH} 2.5$ ) to detect mucin-altered ACF (DIAS et al., 2010). Classical ACF were counted in both the 4-week (A) and 20-week (B) experiments. Mucin-altered ACF were counted only in the 20-week experiment (B). After classical and mucin-altered ACF analysis, samples of the colon were cut into three longitudinal strips, embedded in paraffin, cut into $5 \mu \mathrm{m}$ thick sections and stained with hematoxylineosin (HE) for histological and immunohistochemical analyses.

\section{Immunohistochemical procedures}

In the 20 -week experiment, PCNA and $\beta$-catenin immunohistochemical detection were performed using a Polymer system. Briefly, deparaffinized $5 \mu \mathrm{m}$ colon sections on poly-D-lysine-coated slides were treated sequentially with the following: $3 \%(\mathrm{v} / \mathrm{v}) \mathrm{H}_{2} \mathrm{O}_{2}$ in phosphate-buffered saline (PBS) for $10 \mathrm{~min}$; non-fat milk for $60 \mathrm{~min}$; polyclonal rabbit anti-PCNA (PCNA FL-261, 1:100 dilution; Santa Cruz Biotechnology, Santa Cruz, CA, USA) or $\beta$-catenin ( $\beta$ catenin H-102, 1:500 dilution; Santa Cruz Biotechnology, Santa Cruz, CA, USA) antibodies overnight; Novocastra Post Primary Block for $30 \mathrm{~min}$; and NovoLink Polymer for 45 min (Max Polymer kit; Leica Biosystems Newcastle, UK). Chromogen color development was accomplished with 3,3diaminobenzidine tetrahydrochloride (Sigma, St. Louis, MO, USA). The slides were counterstained with Harris's hematoxylin.

At least 30 perpendicular well-oriented crypts were examined from the colon of each animal from noninitiated groups (groups 5-8) using light microscopy at $400 \times$ magnification. The labeling index of colonic epithelial cells expressing PCNA antigen was evaluated as the percentage of the total number of cells analyzed in each perpendicular normal-appearing colonic crypt (DIAS et al., 2010). The cellular localization of $\beta$-catenin (i.e., membrane, cytoplasm and nucleus) was evaluated in ACF previously detected in the HE-sections from DMH-initiated groups (groups 1-4) (FEMIA; CADERNI, 2008). The percentage of cellular localization of $\beta$ catenin (membrane, cytoplasm and nucleus) was determined for each DMH-initiated group.

\section{Blood parameters and oxidative stress in liver}

In the 20-week experiment, livers were perfused with $0.9 \%(\mathrm{w} / \mathrm{v}) \mathrm{NaCl}$ solution, homogenized in $\mathrm{pH} 7.0$ phosphate buffer and centrifuged for $5 \mathrm{~min}$ at 3,500 rpm. The protein concentrations were determined using Bradford (BRADFORD, 1976) method. Analysis of oxidative damage was performed by measuring the concentration of protein carbonyls (PCO) using a spectrophotometer at $370 \mathrm{~nm}$, using 2,4-dinitrophenylhydrazine and guanidine (EYMARD; BARON; JACOBSEN, 2009). Lipid peroxidation was performed by measuring the concentration of MDA and other TBARS reactive substances using a spectrofluorometer with an excitation wavelength of 532 $\mathrm{nm}$ and an emission wavelength of $563 \mathrm{~nm}$ (RAMEL; WAGNER; ELMADFA, 2004).

Cholesterol, glucose, triglycerides, creatinine and urea were analyzed biochemically using enzymatic colorimetric methods. Analysis of AST (aspartate amino transferase) and ALT (alanine amino transferase) were performed as described by Burtis and Ashwood (2008).

\section{Statistical analysis}

Data on body-weight gain and food consumption were compared among all experimental groups, and the ACF number and multiplicity/colon, mucin-negative ACF number/colon, PCNA and $\beta$-catenin were compared to their respective control groups. ANOVA or KruskalWallis test and post hoc Tukey's test was used according to the required assumptions at the nominal significance level of $5 \%$.

\section{RESULTS AND DISCUSSION}

The incorporation of fruit pulp at $1 \%, 10 \%$ or $20 \%$ (w/w) in the commercial chow was feasible for the development of diets and for the production of pellets for both experiments, with no statistical differences among their nutritional contents as analyzed using the ANOVATukey's test ( $\mathrm{p}>0.05$ ). The average results (in $\mathrm{g} \mathrm{kg}^{-1}$ ) of all diets, including the commercial diet, were as follows: protein $241.6 \pm 10.7$; total fat $33.4 \pm 0.4$; ash $80.2 \pm 3.5$; moisture $121.1 \pm 1.7$ and carbohydrates $523.8 \pm 13.2$. The production of pelleted diets using the same starting ingredients leads to dietary homogeneity, improving the evaluation of their consumption during long-term administration of up to 20 weeks. The mean consumption of the experimental diets was approximately $20.4 \pm 0.6 \mathrm{~g} / \mathrm{rat} /$ day for the 4 -week experiment and $23.1 \pm 0.8 \mathrm{~g} / \mathrm{rat} /$ day for the 20 -week experiment. There were no statistical differences between groups in the body mass and consumption variables (Figure 1) and serum biomarkers (data not shown). However, body-mass gain and food consumption were significantly lower during DMH administration. The monitored variables of body mass, body mass gain and food intake, associated to biochemical serum characteristics, are useful indicators of the good general condition of the animals during the experiment. 

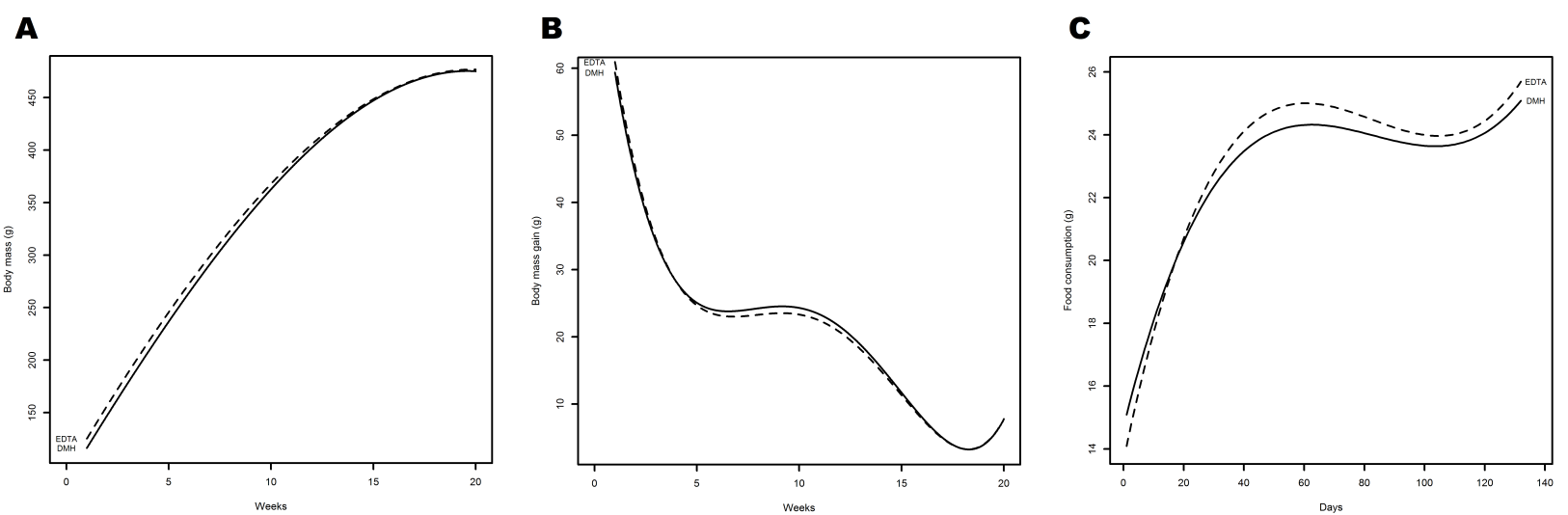

Figure 1- Profile of body mass evolution (A), body mass gain (B) and food consumption (C) in the DMH-initiated groups (groups 1-4) and non-initiated (EDTA) groups (groups 5-8). Data from the 20-week experiment. DMH: 1,2dimethylhidrazine dihydrochloride $(4 \times 40 \mathrm{mg}$ kg-1 b.wt., s.c.). EDTA: DMH vehicle.

The modifying effects of $A$. crassiflora Mart. pulp intake were investigated through experiments involving both early (4 weeks) and late (20 weeks) phases of a chemically induced colon carcinogenesis model. In the first study (4 weeks), only small pre-neoplastic lesions (classical ACF with 1 to 3 aberrant crypts) were induced by $\mathrm{DMH}$ administration and then evaluated. In the second study (20 weeks), three endpoints were chosen: microscopic mucosal lesions (classical ACF, mucinaltered $\mathrm{ACF}$ ), cell proliferation and cell adhesion markers (PCNA and $\beta$-catenin immunostaining), and liver oxidative stress markers (TBARS and PCO). Photomicrographs of all colon endpoints are presented on figure 2 .

The results show that in both experiments, all of the DMH-initiated animals (groups 1-4) developed ACF in the colon, whereas no ACF were observed in the noninitiated groups (groups 5-8). There were no differences between the experimental groups and their respective control groups for ACF number and multiplicity or number of mucin-altered-ACF/colon parameters (Table 1).

In the colonic ACF assay, an increased number of these biomarkers may reflect interference in the initiation step of colorectal carcinogenesis, and a progressive increase in the number of crypts per focus (AC multiplicity) may correspond to a modifying effect on the promotion phase of colon tumorigenesis (DE LIMA et al., 2005; ZHANG et al., 2004). Therefore, the results indicate that the A. crassiflora Mart. pulp intake did not induced carcinogenesis or prevented the DMH effects on the experimental rats colon. The higher multiplicity values of ACF in the 20-week experiment, when compared to the 4week experiment (Table 1), are due to the time progression.

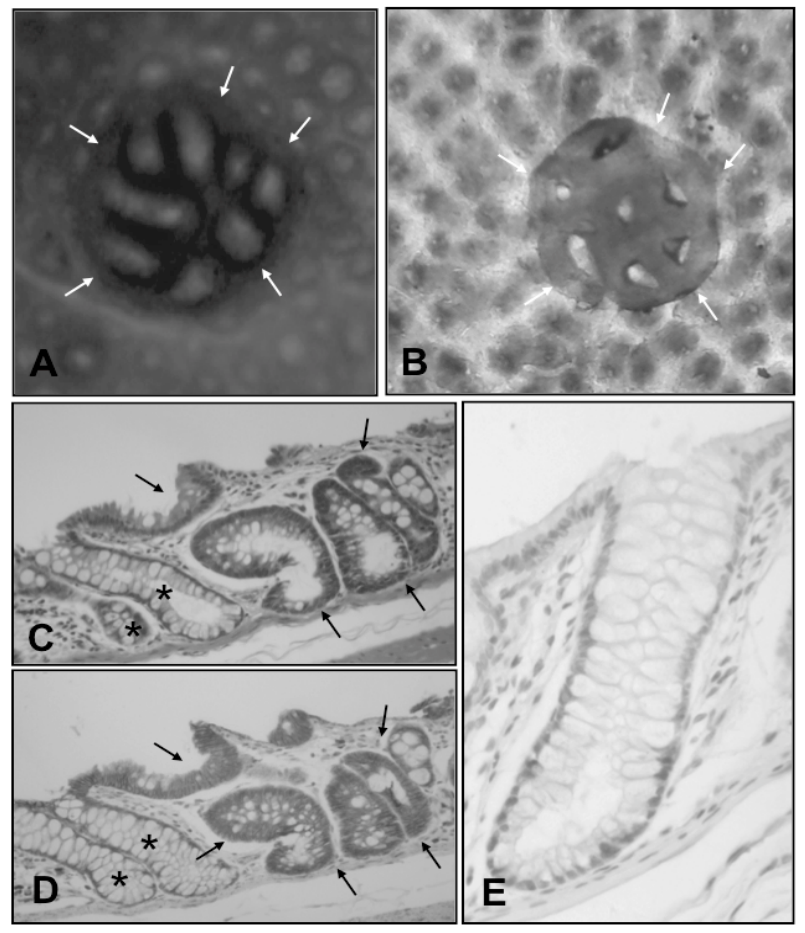

Figure 2-Colon biomarkers: Topographic view of a classical ACF-methylene blue stained with eight aberrant crypts (A, arrows) and a mucin-altered ACF-toluidine blue stained with seven aberrant crypts (B, arrows). Serial colon section showing an ACF identified by HE staining (C, arrows) and a $\beta$-catenin accumulated $\mathrm{ACF}(\mathrm{D}$, arrows) identified by immunohistochemical staining. PCNA labeling in colonic cells (E, dark nuclei) identified by immunohistochemical staining. * Non-altered colonic crypt. 
The results of mucin-altered ACF assays performed in the 20-week experiment indicate that $87-92 \%$ of the ACF with more than 4 aberrant crypts present some level of mucinaltered expression, indicating their potential premalignant phenotype.

PCNA and $\beta$-catenin expression was evaluated in colon sections from non-initiated groups (normal appearing colonic crypts) and DMH-initiated groups (ACF) in the 20-week experiment, in order to assay the modifying effects of A. crassiflora Mart. pulp intake on cell proliferation or premalignant ACF development. The PCNA labeling analysis showed no differences between experimental groups and negative control group (Figure 3A), indicating no correlation between A. crassiflora Mart. pulp intake and increase (harmful) or decrease (protective) of cell proliferation in the colonic crypt without any carcinogenic stimulus. A heterogeneous accumulation of $\beta$-catenin was observed at the cell membrane, in the cytoplasm and in thenuclear compartment of ACF from DMH-initiated groups(groups 1-4) (Figure 3B).

Nevertheless, all three treatment groups showed no significant decrease in aberrant $\beta$-catenin expression compared to the positive control group, including their nuclear localization, which could promote transcription of various target genes (GOSS; GRODEN, 2000).
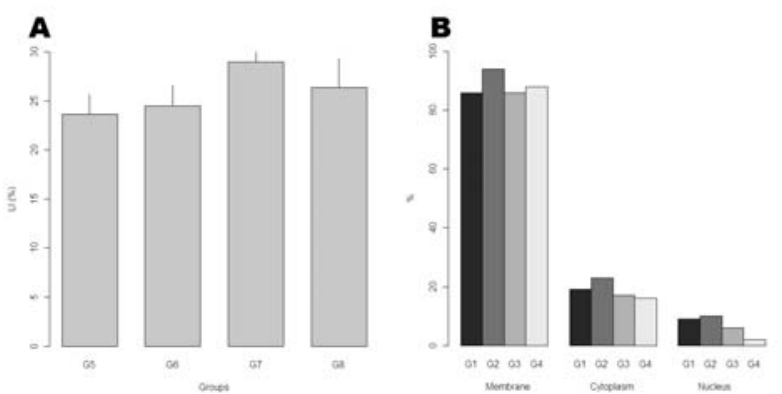

Figure 3 - Effects of A. crassiflora Mart. pulp intake on colonic PCNA labeling indexes (PCNA LI\%) (A) and $\beta$-catenin localization (\% cell membrane, cytoplasm and nuclear).

The results from PCO and TBARS analysis showed no differences between the experimental groups comparing to their corresponding control groups when evaluated in the 20-week experiment. These results varied from $2.00 \pm 1.13$ to $4.11 \pm 2.34 \mathrm{nmol}$ PCO protein $\mathrm{mg}^{-1}$ and from $0.25 \pm 0.11$ to $0.44 \pm 0.11$ nmol TBARS protein $\mathrm{mg}^{-1}$. These results differ from those reported previously (RAJESHKUMAR; KUTTAN, 2003), who administered 
DMH between days 45 and 69 of their experiment and prior to sacrificing the animals, in contrast to days 132 and 108 prior to sacrificing the animals in the present study. The lack of an anti-oxidant effect in our in vivo carcinogenicity model may also result from the utilization of A. crassiflora Mart. pulp as realistic matrix. According to Roesler et al. (2007), the A. crassiflora Mart. pulp has low anti-oxidant activity in in vitro models as assayed using DPPH and low inhibition of lipid peroxidation, due to the smaller content of total phenols $\left(31.08 \mathrm{~g} \mathrm{~kg}^{-1}\right)$ and the predominance of sugars and acids.

\section{CONCLUSIONS}

Our study showed a lack of chemopreventive effect of A. crassiflora Mart. pulp in all tested doses when administered during the initiation and promotion steps of colon carcinogenesis under the morphological, biochemical and immunohistochemical parameters analyzed in vivo. Differently from other in vivo investigations, A. crassiflora Mart. pulp does not potentialize the deleterious effects of DMH carcinogen. This native fruit could be better studied to evaluate potential cancer chemoprevention using further approach on other tissues and systems.

\section{REFERENCES}

\section{ASSOCIATION OF OFFICIALANALYTICAL} CHEMISTS-AOAC. Official Methods of analysis. 16th ed. Washington, DC: Association of Official Analytical Chemists, 2000.

AZEVEDO, L. et al. Black bean (Phaseolus vulgaris L.) as a protective agent against DNA damage in mice. Food and Chemical Toxicology, Oxford, v.41, n.12, p.16711676, 2003.

BIRD, R. P. Role of aberrant crypt foci in understanding the pathogenesis of colon cancer. Cancer Letters, Amsterdam, v.93, n.1, p.55-71, 1995.

BRADFORD, M. M. A rapid and sensitive method for the quantitation of microgram quantities of protein utilizing the principle of protein-dye binding. Analytical Biochemistry, New York, v.72, n.1-2, p.248-254, 1976.

\section{BURTIS, C. A.; ASHWOOD, E. R. Tietz Textbook of} Clinical Chemistry. 4th ed. Philadelphia: Saunders Company, 2008.
DE LIMA, R. O. et al. Modifying effect of propolis on dimethylhydrazine-induced DNA damage but not colonic aberrant crypt foci in rats. Environmental and Molecular Mutagenesis, New York, v.45, n.1, p.8-16, 2005.

DIAS, M. C. et al. Effects of lycopene, synbiotic and their association on early biomarkers of rat colon carcinogenesis. Food and Chemical Toxicology, Oxford, v.48, n.3, p.772-780, 2010.

DRAGANO, N. R. et al. Influence of Marolo (Annona crassiflora Mart.) pulp intake on the modulation of mutagenic/antimutagenic processes and its action on oxidative stress in vivo. Plant Foods for Human Nutrition, Dordrecht, v.65, n.4, p.319-325, 2010.

EYMARD, S.; BARON, C. P.; JACOBSEN, C. Oxidation of lipid and protein in horse mackerel (Trachurus trachurus) mince and washed minces during processing and storage. Food Chemistry, Barking, v.114, n.1, p.57$65,2009$.

FEMIA, A. P.; CADERNI, G. Rodent models of colon carcinogenesis for the study of chemopreventive activity of natural products. Planta medica, Stuttgart, v.74, n.13, p.1602-1607, 2008.

GOSS, K. H.; GRODEN, J. Biology of the adenomatous polyposis coli tumor suppressor. Journal of Clinical Oncology, New York, v.18, n.9, p.1967-1979, 2000.

JASWIR, I. et al. Antioxidant behaviour of carotenoids highly accumulated in HepG2 cells. Food Chemistry, Barking, v.132, n.2, p.865-872, 2012.

KUMAR, V. et al. Growth performance and metabolic efficiency in Nile tilapia (Oreochromis niloticus L.) fed on a diet containing Jatropha platyphylla kernel meal as a protein source. Journal of Animal Physiology and Animal Nutrition, Berlin, v.96, n.1, p.37-46, 2012.

LI, S.-C. et al. Effects of adlay bran and its ethanolic extract and residue on preneoplastic lesions of the colon in rats. Journal of Science of Food and Agriculture, London, v.91, n.3, p.547-552, 2011.

LUTZ, I. A. Métodos físico-químicos para análise de alimentos. São Paulo: ANVISA, 2008. 
RAJESHKUMAR, N. V.; KUTTAN, R. Modulation of carcinogenic response and antioxidant enzymes of rats administered with 1,2-dimethylhydrazine by Picroliv.

Cancer Letters, Amsterdam, v.191, n.2, p.137-143, 2003.

RAMEL, A.; WAGNER, K. H.; ELMADFA, I. Plasma antioxidants and lipid oxidation after submaximal resistance exercise in men. Europeand Journal of Nutrition, Darmstadt, v.43, n.1, p.2-6, 2004.

ROESLER, R. et al. Antioxidant activity of Annona crassiflora: Characterization of major components by electrospray ionization mass spectrometry. Food Chemistry, Barking, v.104, n.3, p.1048-1054, 2007.
VILAR, J.; FERRI,P.; CHEN-CHEN, L. Genotoxicity investigation of araticum (Annona crassiflora Mart., 1841, Annonaceae) using SOS-Inductest and Ames test. Brazilian Journal of Biology, São Carlos, v.71, p.197-202, 2011.

VILAR, J. B. et al. Assessment of the mutagenic, antimutagenic and cytotoxic activities of ethanolic extract of araticum (Annona crassiflora Mart. 1841) by micronucleus test in mice. Brazilian Journal of Biology, São Carlos, v.68, n.1, p.141-147, 2008.

ZHANG, Y. H. et al. Anticancer effect of two diterpenoid compounds isolated from Annona glabra Linn. Acta Pharmacologica Sinica, Beijing, v.25, n.7, p.937-942, 2004. 